\title{
Contextual Effect of Posyandu on Adherence to Iron Tablet Consumption among Pregnant Women in Blitar, East Java
}

\author{
Febrina Ardianti'1), Yulia Lanti Retno Dewi²), Bhisma Murti1) \\ 1)Masters Program in Public Health, Universitas Sebelas Maret \\ ${ }^{2)}$ Department of Public Health, Faculty of Medicine, Universitas Sebelas Maret
}

\begin{abstract}
Background: Anemia in pregnant women remains a health priority to be addressed immediately. Anemia in pregnant women may increase the risk of maternal mortality, abortion, perinatal death, low birth weight, and post partum bleeding. This study aimed to examine the contextual effect of posyandu on adherence to iron tablet consumption among pregnant women in Blitar, East Java.

Subjects and Method: This was a cross sectional study conducted in Blitar, East Java, in November 2018. The dependent variable was adherence of iron tablet consumption. The independent variables were education, intention, attitude, perceived behaviour control, family income, subjective norm, husband support, and posyandu. The data were collected by questionnaire and analyzed by a multilevel linear regression run on Stata 13.

Results: Iron tablet consumption increased with high education $(\mathrm{b}=0.85 ; 95 \% \mathrm{CI}=0.05$ to 1.66 ; $\mathrm{p}=0.038)$, strong intention $(\mathrm{b}=0.40 ; 95 \% \mathrm{CI}=0.02$ to $0.77 ; \mathrm{p}=0.037)$, multiparity $(\mathrm{b}=0.89 ; 95 \%$ $\mathrm{CI}=0.15$ to $1.62 ; \mathrm{p}=0.018)$, positive attitude $(\mathrm{b}=0.29 ; 95 \% \mathrm{CI}=0.15$ to $0.42 ; \mathrm{p}<0.001)$, perceived behavior control $(b=0.33$; $95 \% \mathrm{CI}=0.17$ to 0.48 ; $\mathrm{p}<0.001)$, high family income $(\mathrm{b}=0.05 ; 95 \% \mathrm{CI}=$ 0.01 to $0.10 ; \mathrm{p}=0.018)$, iron tablet availability $(\mathrm{b}=1.62 ; 95 \% \mathrm{CI}=0.84$ to $2.40 ; \mathrm{p}<0.001)$,strong husband support $(b=0.22 ; 95 \% \mathrm{CI}=0.04$ to $0.40 ; \mathrm{p}=0.019)$, and subjective norm $(\mathrm{b}=0.27 ; 95 \%$ $\mathrm{CI}=0.03$ to $0.52 ; \mathrm{p}=0.027)$. Iron tablet consumption decreased with side effect $(\mathrm{b}=-1.22 ; 95 \% \mathrm{CI}=$ -2.12 to $-0.33 ; \mathrm{p}=0.007)$. Posyandu had contextual effect in adherence to iron tablet consumption with ICC $=12.58 \%$.

Conclusion: Iron tablet consumption increases with high education, strong intention, multiparity, positive attitude, perceived behavior control, high family income, iron tablet availability, strong husband support, and subjective norm. Iron tablet consumption decreases with side effect. Posyandu has contextual effect in adherence to iron tablet consumption.
\end{abstract}

Keywords: Fe tablet consumption, posyandu, multilevel analysis

\section{Correspondence:}

Febrina Ardianti. Masters Program in Public Health, Universitas Sebelas Maret. Jl. Ir. Sutami 36A, Surakarta, Central Java 57126. Email: ardiantifebrina@gmail.com. Mobile:+62816609336.

\section{BACKGROUND}

Anemia is a problem of nutritional disorders during pregnancy which is a concern throughout the world, especially in developing countries (Sukrat et al., 2013). Nutrition of pregnant women needs attention because it is very influential on the development of the fetus they contain. Malnutrition at this time is also associated with the risk of chronic diseases in adulthood, namely obesity, heart and blood vessel disease, hypertension, stroke and diabetes. Nutritional pregnancy period for pregnant women must meet their nutritional needs and for fetal growth and development because fetal nutrition depends on maternal nutrition and maternal nutritional needs must also be fulfilled so that they can avoid pregnancy problems, one of which is anemia (Ministry of Health, 2016). Health care facilities that are used as centers for the maintenance and improvement of the health of pregnant women, one of them is integrated community health post (posyandu). The basic 
health services provided at posyandu include services related to $\mathrm{MCH}$ (Maternal and Child Health), family planning, immunization, nutrition and prevention and prevention of disease (Nazri et al., 2016).

WHO data (2016) shows that the prevalence of anemia in pregnant women in the world is $38.2 \%$. The highest prevalence is in the African (46.3\%) and Asia (48.7\%), when it comes to Asia, the highest prevalence is in Southeast Asia is 48.7\%. The results of Riskesdas (2013) show that in Indonesia, $37.1 \%$ of pregnant women experience anemia.

The percentage of coverage of pregnant women in Blitar District in 2014 who received TTD amount to 30 tablets was 87.96\% and those who received 90 tablets were $78.59 \%$, compared to the achievement target, the percentage that received Fe did not meet the target of $90 \%$. Based on these problems the researchers are interested in conducting a study entitled "the contextual influence of posyandu on adherence to taking $\mathrm{Fe}$ tablets in pregnant women in Blitar Regency, East Java".

\section{SUBJECTS ANDMETHOD \\ 1. Study Design \\ This was an analytic observational study with a cross sectional design. It was con- ducted in Blitar, East Java, Indonesia in November 2018.}

\section{Population and Samples}

The source population in this study was pregnant women in 25 community health posts (posyandu) in Blitar, East Java. A sample 200 pregnant women was selected by simple random sampling.

\section{Study Variables}

The dependent variable was Fe tablets consumption. The independent variables were education, family income, intention, attitude, subjective norm, perceived behavior control, and husband's support.

\section{Operational Definition of Variables} Education was defined as the last formal education level pursued to get a diploma.

Family income was defined as income for the past 6 months as a result of economic processes or cumulative economic resources from the family member (husband, wife, and children).

The attitude was defined as positive or negative response of pregnant women's beliefs to the consequences of consuming Fe tablets.

Subjective norm was defined as maternal perception on social pressure to do or not to consume Fe tablets.

Perceived behavior control was defined as maternal perceptions based on beliefs about supporting or inhibiting factors by describing self-efficacy in carrying out a behavior that is consumption of Fe tablets.

Intention was defined as the seriousness of the study subject to do an action or bring up a behavior to consume Fe tablets.

Husband support was defined as the support given by the husband to support the research subject given in the form of good behavior in the form of emotional support (attention, affection, and empathy), spiritual support (teaching worship, and inviting to a place of worship), informational support, instrumental support (assistance for labor, funds, and time), as well as in the form of financial support (funds) to consume $\mathrm{Fe}$ tablets given for the past 1 month.

The side effect was defined as a reaction from consumption of $\mathrm{Fe}$ tablets which is detrimental to pregnant women as a result of administration of Fe tablets.

Parity was defined as the number of children born after 24 weeks' gestation but not abortion, regardless of the baby's life or death. 
Iron tablet availability was defined as the ability of health facilities to provide iron tablet and meet iron tablet need that must be received by pregnant women.

Posyandu strata was defined as a strata at the center of community activities in efforts to provide health and family planning services.

Iron tablet obedience was defined as a condition that describes the compliance of patients in terms of using appropriate drugs based on health staff referrals.

\section{Study Instruments}

The data were collected by questionnaire. Data on posyandu strata were obtained from Blitar annual reports.

\section{Data Analysis}

Univariate analysis was performed to determine frequency distribution of sample characteristics. Bivariate analysis was conducted to study the relationship between iron tablet obedience and independent variables by Pearson product moment. Multivariate analysis was conducted by path analysis.

\section{Research Ethics}

The research ethics include informed consent, anonymity, confidentiality and ethical clearance. The research ethics was obtained from Research Ethics Committee,

\section{Table 1. Sample characteristics}

\begin{tabular}{lccccc}
\hline \multicolumn{1}{c}{ Variable } & N & Mean & SD & Min. & Max. \\
\hline Behavior & 200 & 6.61 & 2.77 & 1 & 11 \\
Subjective norms & 200 & 5.42 & 1.50 & 2 & 7 \\
Behavior control perception & 200 & 6.00 & 2.33 & 1 & 10 \\
Intention & 200 & 2.69 & 0.98 & 1 & 4 \\
Husband support & 200 & 6.25 & 2.18 & 1 & 10 \\
Iron tablet obedience & 200 & 12.25 & 3.65 & 3 & 18 \\
\hline
\end{tabular}

\section{Multilevel Analysis}

Table 2 showed the results of multilevel analysis. Table2 showed that high education $(\mathrm{b}=0.85 ; 95 \% \mathrm{CI}=0.05$ to $1.66 ; \mathrm{p}=$ $0.038)$, high family income $(b=0.05 ; 95 \% \mathrm{CI}=$ 0.01 to $0.10 ; \mathrm{p}=0.018)$, multiparous $(\mathrm{b}=$ $0.89 ; 95 \% \mathrm{CI}=0.15$ to $1.62 ; \mathrm{p}=0.018$ ), iron
Faculty of Medicine, Universitas Sebelas Maret, No. 346 / UNS27.6 / KEPK / 2018.

$\frac{\text { RESULTS }}{\text { 1. Sample characteristics }}$

The characteristic frequency distribution based on Table 1 shows that each variable has a relatively small diversity of data. The mean describes the average value, while the standard deviation (SD) value describes how far the data varies. A small SD value is an indication of representative data. If the $\mathrm{SD}$ value is greater than the mean value, then the mean value is a poor representation of the overall data and the SD value is very small compared to the mean value, the mean value can be used as a representative of the entire data.

Based on table 1, it can be seen that the SD value of each variable was smaller than mean. Attitude $(\mathrm{SD}=2.77$; mean= $6.61)$, subjective norm $(\mathrm{SD}=1.5 \mathrm{O}$; mean $5.42)$, perceived behavior control $(\mathrm{SD}=$ 2.33; mean $=6.00)$, intention $(\mathrm{SD}=0.98$; mean $=2.69)$, husband support $(\mathrm{SD}=2.18$; mean 6.25), and iron tablet obedience $(\mathrm{SD}=$ 3.65 ; mean $=12.25$ ), so that it can be concluded that the data from all variables were representative. tablet availability $(b=1.62 ; 95 \% \mathrm{CI}=0.84$ to 2.40; $\mathrm{p}<0.001)$, positive attitude $(\mathrm{b}=0.29$; $95 \% \mathrm{CI}=0.15$ to $0.42 ; \mathrm{p}<0.001)$, strong intention $(b=0.40 ; 95 \% \mathrm{CI}=0.02$ to $0.77 ; \mathrm{p}=$ 0.037), strong husband support $(\mathrm{b}=0.22$; $95 \% \mathrm{CI}=0.04$ to $0.40 ; \mathrm{p}=0.019$ ), subjective norm $(b=0.27 ; 95 \% \mathrm{CI}=0.03$ to $0.52 ; \mathrm{p}=$ 
0.027), and high perceived behavior control $(\mathrm{b}=0.33 ; 95 \% \mathrm{CI}=0.17$ to $0.48 ; \mathrm{p}<0.001$ ) increased iron tablet consumption obedience. Side effect of iron tablet decreased iron tablet consumption adherence $(\mathrm{b}=-1.22 ; 95 \% \mathrm{CI}=-$ 2.12 to $-0.33 ; \mathrm{p}=0.007)$. Posyandu had contextual effect on iron tablet consumption obedience.

Table 2. Multilevel linear regression

\begin{tabular}{|c|c|c|c|c|}
\hline \multirow{2}{*}{ Iron tablets obedience } & \multirow{2}{*}{$\mathbf{b}$} & \multicolumn{2}{|c|}{$95 \% \mathrm{CI}$} & \multirow[b]{2}{*}{$\mathbf{p}$} \\
\hline & & Lower limit & Upper limit & \\
\hline \multicolumn{5}{|l|}{ Fixed Effect } \\
\hline High education & 0.85 & 0.05 & 1.66 & 0.038 \\
\hline High family income & 0.05 & 0.01 & 0.10 & 0.018 \\
\hline Multiparous & 0.89 & 0.15 & 1.62 & 0.018 \\
\hline Side effect & -1.22 & -0.33 & -0.43 & 0.007 \\
\hline Iron tablet availaibility & 1.62 & 0.84 & 2.40 & $<0.001$ \\
\hline Positive behavior & 0.29 & 0.15 & 0.42 & $<0.001$ \\
\hline Strong intention & 0.40 & 0.02 & 0.77 & 0.037 \\
\hline Strong family support & 0.22 & 0.04 & 0.40 & 0.019 \\
\hline High subjective norm & 0.27 & 0.03 & 0.52 & 0.027 \\
\hline High perceived behavior control & 0.33 & 0.17 & 0.48 & $<0.001$ \\
\hline \multicolumn{5}{|l|}{ Random Effect } \\
\hline \multicolumn{5}{|l|}{ Posyandu } \\
\hline Var (konstanta) & 0.85 & 0.29 & 2.48 & \\
\hline \multicolumn{5}{|l|}{$\mathrm{N}$ observasi $=200$} \\
\hline \multicolumn{5}{|l|}{ Log likelihood $=-470.49$} \\
\hline \multicolumn{4}{|l|}{ LR test vs. linier regression, $\mathrm{p}=0.003$} & \\
\hline $\mathrm{ICC}=12.58 \%$ & & & & \\
\hline
\end{tabular}

\section{DISCUSSIONS}

1. The effect of education on iron tablet consumption obedience

The result of analysis showed that there was a significant effect of education on the adherence of iron tablet consumption.

Dutta et al. (2014) explained that high education affected the awareness of each individual, better insight into various diseases so that a person was able to detect the symptoms early and provide appropriate follow-up. Highly-educated people were able to maintain individual health and be able to maintain family health so that they were able to avoid disease, therefore, pregnant women with high education were more likely to do the recommendations given especially for the sake of the baby.

Based on a study done by Nizar et al. (2014), pregnant women education was 2.29 times to have high adherence to consume iron tablet. Employment, ANC visits, and age also affected the adherence of iron tablet consumption.

\section{The effect of family income on iron tablet consumption obedience}

The result of analysis showed that there was a significant effect of family income on the adherence of iron tablet consumption. Adherence of iron tablet consumption by adhering to all instructions recommended by health personnels to consume iron tablet at least 90 tablets (Sadore et al., 2015).

Income would determine the purchasing power of food that could affect nutritional status so that pregnant women with high family income have a high purchasing power ability to supply nutrients (one of them was iron tablets) and fulfill nutritional needs during pregnancy (Titilayo et al., 2016). 


\section{The effect of parity on iron tablet consumption obedience}

The result of analysis showed that there was a significant effect of parity on the adherence of iron tablet consumption. Parity was the number of children born, both alive and born in a state of death. The higher the parity, the higher the maternal mortality and the risk that would occur both in pregnancy and the puerperium (Manuaba, 2012).

Multiparous mother had higher adherence compared to nulliparous mothers because mothers with multiparous parity have more experience and good thinking related to their health (Anggraini, 2018).

\section{The effect of side effects on iron tablet consumption obedience}

The result of analysis showed that there was a significant effect of side effects on the adherence of iron tablet consumption. Kamau and Kimani (2018) explained that the adherence of iron tablet consumptionin pregnant women was affected by counseling, side effect, and awareness.

Side effect after consuming iron tablet was one of the main factors which caused low maternal adherence. Pregnant women with low adherence to iron tablet consumption reported that they experienced nausea and vomiting after consuming iron tablets so that they decided not to consume the tablets anymore (Achadi, 2013).

\section{The effect of iron tablet availability on iron tablet consumption obedience}

The result of analysis showed that there was a significant effect of iron availability on the adherence of iron tablet consumption Fe.

Iron tablet availability affected the iron tablet consumption obedience. Iron tablet availability in health facility would increase the adherence of iron tablet consumption because the need for iron tablets in pregnant women was sufficient (Dewantoro and Muniroh, 2017).

\section{The effect of attitude on iron tablet consumption obedience}

The result of analysis showed that there was a significant effect of attitude on the adherence of iron tablet consumption. Sunaryo (2013) explained that attitude was a person's closed response to a stimulus or information, both internal and external so that the manifestations cannot be directly seen, but can only be interpreted in advance of the closed behavior.

Nivedita and Fatima (2016) explained that attitude affected the adherence of iron tablet consumption. A positive attitude toward iron tablets consumption was very important for pregnant women so that the adherence of iron tablet consumption behavior was formed, attitudes were influenced by the level of education and knowledge, high education with good knowledge related to the importance of consumption of iron tablets would increase the maternal positive attitude toward iron tablet consumption.

\section{The effect of intention on iron tablet consumption obedience}

The result of analysis showed that there was a significant effect of intention on iron tablet consumption obedience.

Intention was a desire which followed by action, and this intention was an indicator to rectify an action (Fishbein and Yzer, 2003). In general, the better the attitude and subjective norms, the stronger the intention of someone to do the intended behavior (Istiqomah, 2014). This was in accordance with the results of the study which showed that the adherence to consume iron tablets was also influenced by subjective attitudes and norms. 


\section{The effect of husband support on iron tablet consumption obedience}

The result of analysis showed that there was a significant effect of husband support on of iron tablet consumption obedience.

Khautsar et al. (2013) explained that the involvement of the husband as a form of support since the beginning would be very useful to maintain maternal emotion so that the mother felt calm and confident, in addition, if every family hoped for pregnancy, supporting and even showing support in various ways, it would further increase maternal adherence with ANC visits so the mother routinely got iron tablets according to the schedule of visits.

Based on a study conducted by Nizar et al. 2014) it showed that social supports from family, peers, and health personnels were1.97 times more likely to increase high adherence to iron tablet consumption in pregnant women compared to pregnant women who rarely conduct ANC visit.

\section{The effect of subjective norm on iron tablet consumption obedience} The result of analysis showed that there was a significant effect of subjective norm on iron tablet consumption obedience.

Subjective norm was perception of social pressure in environment. This social pressure would affect someone's decision to conduct a behavior or not (Ajzen, 2005).

Hamilton et al., (2011) explained that with the existence of subjective norms that support the adherence of iron tablets consumption, pregnant women could increase the adherence to take iron tablets because of the support provided, therefore, the mothers would consume iron tablets regularly.

\section{The effect of perceived behavioral control on iron tablet consump- tion obedience}

The result of analysis showed that there was a significant effect of perceived behavior control on iron tablet consumption obedience. Ajzen (2005) stated thatperception was a process that arised due to the activity (service received) that can be felt by an object. It was because everyone's perception of an object (service) was different.

Sadore et al. (2015) explained that adherence to take iron tablet in pregnant women was influenced by a positive perception of the function of iron tablet consumption, in addition, ANC visits and education also affected the adherence of iron tablet consumption.

11. The effect of posyandu on iron tablet consumption obedience

The result of analysis showed that there was a significant effect of Posyandu level on iron tablet consumption obedience.

The aim of the Posyandu program was to maintain and improve pregnant women health by provide iron tablet (Nazri et al., 2016).

Based on the results of this study, iron tablet consumption increases with high education, strong intention, multiparity, positive attitude, perceived behavior control, high family income, iron tablet availability, strong husband support, and subjective norm. It decreases with side effect. Posyandu has contextual effect in adherence to iron tablet consumption.

\section{REFERENCES}

Achadi, Endang E, Laksminingsih. (2013). Faktor-faktor yang Berhubungan dengan Kepatuhan Ibu Mengkonsumsi Tablet Besi-Folat Selama Kehamilan. Jurnal Gizi dan Pangan, 8(1): 63-70.

Ajzen I (2005). Perceived Behavioral Control, Self-Efficacy, Locus of Control, and the Theory of Planned Behavior. Journal of Applied Social Psychology, 32: $665-683$. 
Anggraini DD (2018). Faktor Predisposisi Ibu Hamil dan Pengaruhnya terhadap Kepatuhan Mengkonsumsi Tablet Besi (FE) dan Anemia pada Ibu Hamil. Strada Jurnal Ilmiah Kesehatan. 7(1): $9-22$.

Dewantoro NKP, Muniroh L (2017). Studi deskriptif program suplementasi tablet besi pada ibu hamil di Puskesmas Kaliju dan Kota Surabaya. Amerta Nutrition, 1(4): 308. https://doi.org/10.20473/amnt.v1i4.2017.30 8-317.

Dutta AJ, Patel P, Bansal RK (2014). Compliance to iron supplementation among pregnant women: a cross sectional study in Urban Slum. National Journal of Community Medicine, 5:4.

Fishbein M, Yzer MC (2003). Using theory to design effective health behavior interventions. Communication Theory. International Communication Association, 32: 164-183.

Hamilton K, Daniels L, White KM, Murray M, Walsh A (2011). Predicting Mothers' decisions to introduce complementary feeding at 6 months. An Investigation Using an Extended Theory of Planned Behaviour. Appetite, 56: 674-681.

Istiqomah E (2014). Hubungan sikap dan norma subyektif dengan niat mengkonsumsi tablet suplementasi besi pada ibu hamil di Banjarmasin. Jurnal Psikologi Teori \& Terapan, 4(2): 106 - 112.

Kamau M, WandKimani S (2018). Compliance with iron and folic acid supplementation (IFAS) and associated factors among pregnant women: results from a cross-sectional study in Kiambu County, Kenya. BMC Public Health, 18: 580 .
Kementerian Kesehatan Republik Indonesia (2016). Data dan informasi 2016 (Profil Kesehatan Indonesia). Jakarta.

Manuaba (2012). Ilmu kebidanan, penyakit kandungan dan KB. Jakarta: EGC.

Nazri C, Yamazaki C, Kameo S, Dewi MD, Herawati, Nanan S, Raksanagara A, Koyama H (2016). Factors Influencing mother's participation posyandu in Aceh Utara District, Aceh Province, Indonesia. BMC Public Health, (16): 69.

Nisar YB, Dibley MJ, Mohammad AM. (2014). Factors associated with nonuse of antenatal iron and folic acid supplements among Pakistani women: a Cross Sectional Household Survey. BMC Pregnancy and Childbirth, 14: 305.

Nivedita K, Fatima SN (2016). Knowledge, attitude and practices of pregnant women regarding anemia, iron rich diet and iron supplements and its impact on their hemoglobin levels. Int J Reprod Contracept Obstet Gynecol, 5(2): 425-431.

Riset Kesehatan Dasar (Riskesdas). (2013). Badan penelitian dan pengembangan kesehatan kementerian RI tahun 2013. Diakses: 19 Juli 2018, dari http://www.depkes.go.id/resources/d ownload/general/Hasil\%2oRiskesdas \%202013.pdf.

Sadore AA, Gebretsadik LA, Mamusha AH (2015). Compliance with iron-folate supplement and associated factors among antenatal care attendant mothers in misha district, south ethiopia: community based cross-sectional study. Journal of Environmental and Public Health. http://dx.doi.org/10.1155/2015/781973.

Sukrat B, Wilasrusmee C, Siribumrungwong B, McEvoy M, Okascharoen C, 
Attia R, Thakkinstian A (2013). Hemoglobin concentration and pregnancy outcomes: a systematic review and meta-analysis. BioMed Research International, 2: 9. http://dx.doi.org/10.1155/2013/769057.

Sunaryo (2013). Psikologi untuk keperawatan. Jakarta: EGC.

Titilayo A, Agunbiade OM, Banjo O, Lawani A. (2016). Menstrual discomfort and its influence on daily academic activities and psychosocial relationship among undergraduate female students in Nigeria.Tanzan J Health Res, 11(4): 181-188.

World Health Organization (2016). Daily iron and folic acid supplementation in pregnant women. Geneva: World Health Organization. 